\title{
MANAGEMENT QUALITY CONTROL IN ISLAMIC EDUCATION
}

\author{
Rangga Sa'adillah S.A.P1), Daiyatul Husna2), Dewi Winarti3) \\ STAI Taswirul Afkar Surabaya Indonesia, http://orcid.org/0000-0002-6626-70021 \\ PW. Fatayat NU Jawa Timur Indonesia² \\ PW. Fatayat NU Jawa Timur Indonesia ${ }^{3}$ \\ Email: rangga@taswirulafkar.ac.id¹, daiyatulkhusnah@gmail.com², dewiwinarti@gmail.com³
}

Dikirim: 13 Februari 2021 | Direvisi: 21 Maret 2021 | Dipublikasikan: 31 July 2021

\begin{abstract}
This article aims to examine and elaborate on the terms of quality control management from the perspective of Islamic education. Quality control is important in the world of education because quality control is related to the consistency of Islamic education institutions in ensuring that the quality of these educational institutions is feasible to operate and compete in the national and international education arena. To control the quality of education, this article offers two models, namely total quality management and excellent servicebased quality control management. The thing that must be considered in quality control management is not only to pay attention to three aspects of quality control, namely input, process, and output. More than that, in carrying out quality control management, you must also provide excellent service that really shows partiality to the customer or stakeholder.

Keywords: Islamic education management; quality of Islamic education; Total Quality Management, Islamic education management based on excellent service.
\end{abstract}

\section{Introduction}

Quality plays an important role in developing the country. The effort to build a country to be of good quality is to commit to fixing education based on quality or quality. Although there is a long dialectic of terms of quality according to some experts, in short, quality can be referred to as quality.

There are at least three reasons why in education it is necessary to consider. The first is the issue of the reputation of the education provider. It is clear that the implementation of education in this country refers to the SNP which consists of eight components. If an educational unit cannot fulfill the SNP component, then the reputation of the education unit should be doubted. The second is product responsibility. Whether it is realized or not, educational institutions today are almost like companies that have raw input, process, and output (graduates/products). The higher the quality of the educational unit, the better the quality of the products or graduates produced so that when the products or graduates return to society their quality will still be recognized. The third is the impact of quality Quality education units should be able to produce quality graduates, quality graduates can have an impact on society. From the impact given to the community, the community will provide feedback or review about the satisfaction of the products produced by the education unit so that from the community's response, the results will be obtained whether the education unit is of good quality or not. 
Maintaining the quality of education means maintaining the consistency of education units in managing the educational process, also producing education graduates, and also providing accountability to the community. Maintaining the quality of education requires management, or knowledge to regulate. This is the importance of regulating the quality of education because it is true what Sahabat Ali bin Abi Talib said, unregulated goodness can be defeated by regulated evil. ${ }^{1}$

Accordingly, education is a major factor in shaping the human person. Realizing this, the government is very serious about dealing with education in Indonesia. The government continues to be committed to improving education through juridical, executive, conceptual, and action efforts. If we look at it within a decade, how many nasikh and mansukh laws are only for managing the education sector, such as PP. 19 of 2005 which has undergone two changes, namely PP 32 of 2013 which was then replaced with PP 13 of 2015, even recently it was renewed with PP 57 of 2021.

Regarding quality control and assurance, the government has specifically regulated Permendikbud Number 28 of 2016. ${ }^{2}$ PP No. 28 of 2016 is also a replacement for the Minister of Education Regulation No. 63 of 2009. The juridical journey of education quality assurance is also proof that the government pays serious attention to the aspects of education, because in $2016 \mathrm{PP}$ No. 28 specifically mentions quality assurance at the level of primary and secondary education units or Dikdasmen which was previously in 2009 Minister of Education Regulation No. 63 has not specifically mentioned the education unit. Then with the issuance of PP. 28 of 2016 concerning the quality assurance of Dikdasmen also triggered the birth of Permenristek Dikti No. 62 of $2016 .^{3}$ Thus, the juridical foundation and the government's commitment to regulating education quality assurance regulations are complete.

Following up on the importance of efforts to study and elaborate on the concepts of education quality assurance in order to realize quality education, this article seeks to conduct an indepth study of the terms of education quality control management and the efforts at least made to achieve quality education. Through an in-depth study of the latest library sources obtained from journal articles and several reference sources from books, this article offers two quality assurance management to be applied in Islamic educational institutions, namely, total quality management and excellent service-based quality management.

\section{Elaborating on Education Management and Quality Control Terms}

The origin of the word management is taken from the word to manage which means to organize. Globally management is a science and art to manage resources through an activity that a group of people or individuals do in order to later achieve the desired goals of the organization or agency itself. ${ }^{4}$ Four main things that are summarized from the understanding of management, namely:

First, an art and a science. Management is a science because, in principle or concept, management can be learned. The art of management is unique to every manager in managing

\footnotetext{
${ }^{1}$ Rangga Sa'adillah S.A.P., "Formulasi Kebijakan Pembelajaran Pendidikan Agama Islam; Refleksi Filosofis Kebijakan Permendikbud No . 22 Tahun 2016 Pada PAI," El-Banat: Jurnal Pemikiran dan Pendidikan Islam 10, no. 22 (2020): 75 90.

${ }^{2}$ Mendikbud, Permendikbud No. 28 Tabun 2016 Tentang Sistem Penjaminan Mutu Pendidikan Dasar Dan Menengah, Kemdikbud, 2016.

${ }^{3}$ Menristekdikti, Permenristekdikti No 62 Tabun 2016 Tentang Sistem Penjaminan Mutu Pendidikan Tinggi (Indonesia, 2016).

${ }^{4}$ Abdul Hadi, "Konsepsi Manajemen Mutu Dalam Pendidikan,” Idaarah: Jurnal Manajemen Pendidikan 2, no. 2 (2018): 269.
} 
resources through his leadership at an agency or organization. Second, manage resources. To produce a weighted output, the resources must be managed in a surefire way, and to be able to support weighted results required qualified resources in the field of management. Third, the achievement of a goal. It is undeniable that an agency and/or institution must have a purpose, it will be brought and made what an institution must have been carefully designed by the resources in it, especially the leadership who has full responsibility for the institution it leads. Fourth, activities are carried out in groups. A management activity will be successful if done jointly because the management will be lame if it runs alone. Therefore management will inevitably have to involve others, so there will be coordination between management actors. Through the work done in groups, there will be a division of tasks or called job description. ${ }^{5}$

Asrohah describes the four management functions as follows: First, planning. Planning is essentially a decision-making activity about what goals it will achieve, what actions will be taken to achieve that goal or objective, and who will carry out the task. The creation of an organization activity plan requires each member of the organization not to neglect the vision, mission, and objectives of the organization that have been created together. Second, organizing. Organizing can be interpreted as the activity of dividing tasks to people involved in the organization. Organizing also serves to set up a clear system of cooperation, who runs what, who is responsible for whom and focuses resources on goals. One of the principles of organizing is the dividedness of all tasks in various elements of the organization professionally and proportionately, in other words, effective organizing is dividing and structuring tasks into organizational components. Organizing also regulates the mechanism of action of the organization, so that such arrangements can guarantee the specified objectives. Third, mobilization. Mobilizer is a management function to realize the results of planning and organizing. Mobilization is an effort to mobilize or direct manpower and utilize existing facilities intended to carry out work together. Mobilization is strongly related to the use of various organizational resources, therefore the ability to lead, motivate, communicate, create a conducive organizational climate and culture is the key to mobilization. Fourth, surveillance. Supervision is a useful management function to know how far a predetermined plan can be achieved. That oversight can help leaders measure the effectiveness of planning, organizing, and execution that occur in the field, and can help leaders to take accurate actions or decisions as organizational needs. Good supervision requires supervisory measures, namely: determining the objectives of expected quality standards of work and measuring and assessing activities based on established objectives and standards. And the last is to decide to take corrective action when necessary. ${ }^{6}$

The quality of education is a multi-dimensional, dynamic concept that refers not only to the educational model but also to its institutional mission and objectives, as well as specific standards of systems, facilities, programs, or events. ${ }^{7}$ While another definition is presented by Jamaluddin quoting the opinions of Bayne-Jardine, Hoy, \&Wood. Quality in education is an evaluation of the process of educating which enhances the need to achieve and develop the talents of the customer

\footnotetext{
${ }^{5}$ Ibid.

${ }^{6}$ Hanun Asrohah, "Manajemen Mutu Pendidikan," Government of Indonesia (GoI) and Islamic Development Bank (IDB) (Surabaya: Universitas Islam Negeri Sunan Ampel Surabaya, 2015).

${ }^{7}$ Hadi, "Konsepsi Manajemen Mutu Dalam Pendidikan."
} 
of the process, and at the same time meets the accountability standards set by the clients who pay for the process or the outputs from the process of educating. ${ }^{8}$

Paying attention to various exposures about the definition of quality management of education can be outlined the definition of quality management of education is a way of managing educational institutions that are comprehensive and integrated to meet the needs of customers consistently and achieve continuous improvement in every aspect of educational institution activities. $^{9}$

Jamali summarizes the definition of a quality control system. In the summary, Jamali quality control is called the term quality control. Quality control is a system of routine technical activities designed to measure and assess the quality of products or services provided to customers. Control is needed to ensure that the activities are following the established plan so that the products produced are under the expectations and needs of customers. Quality control tasks can be performed by measuring differences such as planning, designing, using appropriate procedures or equipment, inspections, and correcting things that deviate. ${ }^{10}$

Jamali elaborated his definition of quality control by referring to some opinions, such as Amitava Mitra, which says that, quality control may generally be defined as a system that is used to maintain a desired level of quality in a product or service. While Tzvetelin Gueorguiev, stated that, quality control as processes are monitored to ensure that all quality requirements are being met and performance problems are solved.. ${ }^{11}$

Considering the opinions above can be outlined that the quality control system covers the entire process and activities in producing or producing products and services that are from the process of developing new products until the product is used by customers satisfactorily. In line with the concept of quality control, education quality control targets three aspects, namely input, process, and output. ${ }^{12}$

\section{Purpose and Function of Quality Control}

Quality control is basically an organizational tool that is functioned to produce quality products or services so that customers and producers are satisfied. ${ }^{13}$ Sukmadinata explained the purpose of quality control is to take measurements and improvements so that what has been planned can be achieved to the maximum. ${ }^{14}$ Herawan cited Juran's opinion that the main purpose of control is to minimize damage with a quick and appropriate diagnosis to restore the quality of the product or service for the better. ${ }^{15}$ Furthermore, Herawan cites Lindsay's opinion: control, therefore, is doing whatever is needed to accomplish what we want to do as an organization. Meanwhile, when referring to PP No. 28 of 2016, the quality assurance system aims to ensure the fulfillment of standards in the education unit systemically, holistically, and sustainably, to grow and

\footnotetext{
8 Jamaluddin, Manajemen MutuTeori Dan Aplikasi Pada Lembaga Pendidikan, ed. Kasful Anwar Us (Jambi: Pustaka Jambi, 2017).

9 Asrohah, "Manajemen Mutu Pendidikan."

${ }^{10}$ Yusra Jamali, “Konsep Pengendalian Mutu Pendidikan,” Tarbawy: Jurnal Pendidikan Islam 1, no. 2 (2016): 304-318.

${ }^{11}$ K Ishikawa and D J Lu, Pengendalian Mutu Terpadu (PT. Remaja Rosdakarya, 1992).

12 Jamali, "Konsep Pengendalian Mutu Pendidikan."

${ }^{13}$ Endang Herawan, "Pengendalian Mutu Pendidikan: Konsep Dan Aplikasi," Jurnal Administrasi Pendidikan 13, no. 1 (2011).

${ }^{14}$ Nana Syaodih Sukmadinata, "Pengendalian Mutu Pendidikan Sekolah Menengah," Bandung: Refika Aditama (2006).

15 Herawan, "Pengendalian Mutu Pendidikan: Konsep Dan Aplikasi."
} 
develop a quality culture in the education unit independently. While the function of quality assurance is to control the implementation of education by the education unit in primary and secondary education so that quality education is realized. ${ }^{16}$

\section{Objects and Targets of Quality Control}

Quality control can run well while quality control prerequisites are carried out. Hiryanto stated that the first prerequisite that is met in quality control is planning. Quality control must be based on clear, complete, and integrated planning so that the planning is more effective than the quality control system can be implemented properly. Both have clear organizational structures. As the purpose of quality control is to make assessments and improvements so that what has been planned can be achieved optimally. ${ }^{17}$

When described quality control procedures can be described as follows:

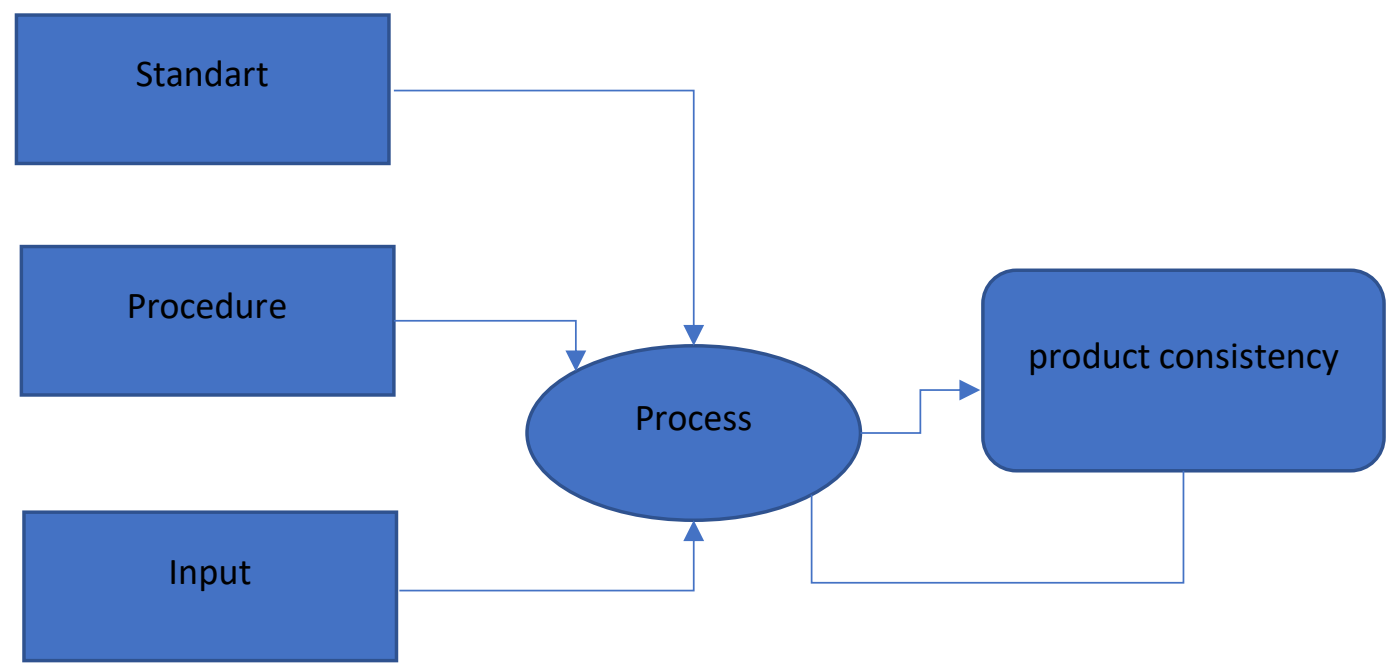

\section{Image 1. Quality Control Procedures. Source Hiryanto.}

The picture above explains that the quality control process is done first by setting standards such as those in the SNP (Standar Nasional Pendidikan) and procedures especially related to the production process (in learning) to process raw inputs to produce out put that can meet customer expectations consistently. Completing the above opinion, Sukmadinata ${ }^{18}$ mentioning four stages in the quality control process: 1) planning, namely drawing up goals and standards; 2) measurement of real performance; 3) compare the performance of measurement results with standard performance; 4) improve performance. It has been outlined in the definition of control above that there are three objectives in education quality control activities, including educational input, educational process, and educational output.

\footnotetext{
${ }^{16}$ Mendikbud, Permendikbud No. 28 Tahun 2016 Tentang Sistem Penjaminan Mutu Pendidikan Dasar Dan Menengah.

${ }^{17}$ Hiryanto, "Pengendalian Mutu Program Pendidikan Non Formal Dan Informal" (Yogyakarta: Bahan Diklat Fungsional Penilik, 2010).

18 Sukmadinata, "Pengendalian Mutu Pendidikan Sekolah Menengah."
} 
In PP No. 28 of $2016,{ }^{19}$ quality control objectives can be observed in article 7 , that quality control objectives concerning some data and information include: ${ }^{20} 1$ ) educational outcomes; 2 ) educational content; 3) the educational process; 4) educational assessment; 5) teachers and educational personnel; 6) educational infrastructure; 7) education financing, and 8) education management.

The education quality control objectives in PP No. 28 of 2016 above are actually in sync with the mandate of PP No. 19 of 2005. Meanwhile, Sukmadinata tries to summarize the target of quality control of education covering several aspects, namely curriculum, personnel management, students, facilities, and infrastructure. ${ }^{21}$

Hiryanto mentioned that the nature and timing of quality control of education can include eight aspects, as follows: 1) accurate, meaning that the information generated from the control must be correct; 2) timely, information must be obtained periodically so that improvement efforts can be provided periodically as well; 3) objective and comprehensive, the quality control system must be understood by everyone involved; 4) focused on strategic control objectives, control should be focused on targets so that deviations from standards can be immediately known; 5) economically and organization realistic, quality control system is easy to do at low cost; 6) flexible, quality control of education must be flexible enough in the face of unusual things or facing unexpected events or unexpected events; 7) prescriptive and operational, if performance standards are not found, the quality control system must indicate what action to take; and 8) acceptable to organization members), the quality control system must be acceptable to all members of the organization.

\section{Total Quality Management}

The concept of Total Quality Management (TQM) or can be called integrated quality management has been successfully applied in the business world and has proven its success so that there is currently an effort to implement TQM in the field of education, especially on the school line, after going through the adaptation and modification process as necessary. ${ }^{22} \mathrm{TQM}$ is a controlling activity conducted by a person or institution to make a total arrangement of things that are very beneficial for the common good. ${ }^{23}$

Several complete definitions of TQM can be observed in Jamaluddin's opinion. Citing his opinion Kanji \&Wallace TQM defined, TQM as the culture of an institution committed to customer satisfaction through continuous improvement. A fuller definition was put forward by Sashkin \&Kiser, TQM means that the institution's culture is defined by and supports the constant attainment of customer satisfaction through an integrated system of tools, techniques, and training. This involves the continuous improvement of institutional processes, resulting in high-quality product and services.

TQM is briefly defined by Jamaludin as a strategy and process for managing companies/organizations/institutions as an integrated system of principles, methods, and best practices that provide a framework for organizations to pursue excellence in everything they do under top management leadership and commitment, supported by education and training, open communication, change

\footnotetext{
${ }^{19}$ Mendikbud, Permendikbud No. 28 Tahun 2016 Tentang Sistem Penjaminan Mutu Pendidikan Dasar Dan Menengah.

${ }^{20}$ RI, Peraturan Pemerintah Republik. Indonesia Nomor 19 Tabun 2005 Tentang Standar Nasional Pendidikan (Indonesia: 19 Tahun 2005, 2005).

${ }^{21}$ Sukmadinata, "Pengendalian Mutu Pendidikan Sekolah Menengah."

22 Titin Untari, "Implementasi Penjaminan Mutu Pendidikan Untuk Meningkatkan Mutu Pembelajaran," in Seminar Nasional Kedua Pendidikan Berkemajuan Dan Menggembirakan (Seminar Nasional Kedua Pendidikan Berkemajuan dan Menggembirakan, n.d.), 389-400.

${ }^{23}$ Dona Andora and Hade Afriansyah, "Pengendalian Manajemen Mutu Terpadu (Total Quality Management)" (2019).
} 
management, periodic self-assessment, supportive structures, systems and resources that empower employees through their involvement to improve their performance as a team to deliver continuously improved products and services. ${ }^{24}$

According to Prasojo, ${ }^{25}$ TQM has several basic elements, as follows: 1) a firm management commitment to quality; 2) focus on consumer demand and expectations; 3) prevention of the manufacture of defective products takes precedence; 4) realize that responsibility concerning quality is universal; 5) quality measurement; 6) sustainable development approach in conducting business or service; 7) corrective actions that reach the root of the blame; 8) worker engagement and empowerment; 9) teamwork synergy; 10) process development; 11) think statistically; 12) benchmarking; 13) Inventory reduction (waste reduction); 14) value development; 15) grouping of suppliers; and 16) training.

Hiryanto $^{26}$ mentions the elements of TQM include: first, including the organizational system. In the organizational system, it can be known that the organization also has an orderly system and must be organized based on an unfounded thing because the organization is a unity of an orderly system and must be organized based on an unfounded thing because the organization is a unity of a system that must be integrated properly. Second, customer value strategy. It is a strategy that assesses how the benefits or benefits felt by customers to the products produced and also how customers sacrifice to get the results purchased or enjoyed by customers. Third, continuous quality improvement. Quality is a measuring instrument of how good a thing is and certainly, quality or quality is not a static or rigid thing, but a dynamic that can change both in the direction of the better and in the worse direction. Good quality must be maintained in a sustainable manner in order for things to be better.

Andora dan Afriansyah ${ }^{27}$ explain the three principles of TQM. First, customer satisfaction. It is something that must be considered by every education unit or stakeholder because the customer is the person who will buy the product (graduate) or use the product (graduate) so that the education unit can feel the advantage of the purchased product. Customer satisfaction is so important to note. The second, factbased management. A matter must be based on facts because otherwise based on facts will be asked where the validity of the authenticity of the information and manage well and correctly how a fact can be submitted and said to be true and tested for truth. Third, respect for each employee. Each employee has different potentials because people in fact have competencies that are not the same as others even though they have blood. Giving respect to employees in this case is a teacher in an effort to improve the quality of the learning process because the focus of the learning process lies with the teacher.

\section{Management Quality of Excellent Service-Based Education}

Barnawi dan Arifin ${ }^{28}$ explained that educational institutions are institutions that serve to provide educational services to the public. The expectation that the public wants for the services performed by educational institutions is an easy service, without compassion, honesty, fairness, and others. Through this hope, the education provider is obliged to fulfill the wishes of its customers and must be able to satisfy its customers. Service that gives satisfaction to customers or that is per customer expectations, even more, so-called excellent service.. ${ }^{29}$

\footnotetext{
${ }^{24}$ Jamaluddin, Manajemen MutuTeori Dan Aplikasi Pada Lembaga Pendidikan.

${ }^{25}$ Lantip Diat Prasojo, Maajemen Mutu Pendidikan, UNY Press (Yogyakarta: UNY Press, 2016).

${ }^{26}$ Hiryanto, "Pengendalian Mutu Program Pendidikan Non Formal Dan Informal."

27 Andora and Afriansyah, "Pengendalian Manajemen Mutu Terpadu ( Total Quality Management)."

${ }^{28}$ Barnawi and M. Arifin, "Sistem Penjaminan Mutu Pendidikan Teori \& Praktik," Yogyakarta: Ar-Ruzz Media (2017). ${ }^{29}$ Ibid.
} 
The essence of service is to give something to the other party. While prime can be interpreted as primary, perfect, or excellent. Prima can also be said to exceed the expectations of the parties served. Thus, excellent service is a satisfactory service or service that can meet the needs of customers without any complaints. ${ }^{30}$ When identified, excellent service management has 10 characteristics, including: 1) tangible; 2) reliability; 3) responsiveness; 4) competence; 5) access; 6) courtesy; 7) communication; 8) credibility; 9) security; 10) understanding the customer.

Then when identified indicators, excellent service there are four indicators. First, it's easy and fast. In principle, the pattern and system of excellent service should be designed simple, easy to understand by both parties, namely waiters and customers. Easy and fast service at this time can be supported by the sophistication of technology so that the service can be accessed anywhere and anytime by customers and service providers. Second, openness. Excellent service should be able to make customers feel sincere, sincere, and open. The thing to avoid from service is to outsmart customers in which case customers can be disappointed. Service providers must also be able to provide commitments to customers, commitments in the form of promises must be consistently kept by service providers. Third, pay attention to the needs. It takes listening skills and feeling what the customer wants. Therefore, it is better if the service provider can understand the customer's wishes, such as first conducting a survey or simple research to understand the wants and needs of customers. Fourth, familiar. Excellent service can at least build a civil atmosphere with customers so that customers feel appreciated and respected. Building a familiar atmosphere with customers can create a good communication relationship between service providers and customers. Humanist service provider attitude such as honest, polite, energetic, and appreciative will make customers feel satisfied and at home with the services provided.

In terms of education, excellent service-based management pays attention to several aspects, such as 1) excellent service is the best service from the school to the parents/guardians of students; 2) excellent service based on the best service standards; 3) schools that do not have a standard of service, the prime service model is the Minimum Service Standard (SPM [Standar Pendidikan Minimal); 4) the designated school has achieved SPM, the excellent service is the National Standard of Education (SNP [Standar Nasional Pendidikan]); 5) schools that have achieved the SNP, excellent service is a quality standard based on local excellence. In addition, it can also be quality standards from the results of adopting and adapting certain international standards. $^{31}$

\section{Conclusion}

Paying attention to the descriptions of education quality control management, it can be reflected that quality control is an urgent thing to do in educational institutions, especially Islamic educational institutions. Paying attention to quality control means maintaining the consistency of these educational institutions to continue to be trusted and used by the public at large. Quality control of education needs to be controlled with management science. Following the essence of management science that means governing, it is at least necessary to control the quality of education management model that is compatible and under the mandate of eight national standards of education. The two models of education quality assurance management outlined in this paper can

\footnotetext{
${ }^{30}$ Rahman Tanjung et al., "Manajemen Pelayanan Prima Dalam Meningkatkan Kepuasan Mahasiswa Terhadap Layanan Pembelajaran (Studi Kasus Di STIT Rakeyan Santang Karawang)," Jurnal Ilmiah MEA (Manajemen, Ekonomi, \& Akuntansi) 3, no. 1 (2019): 234-242.

31 Barnawi and Arifin, "Sistem Penjaminan Mutu Pendidikan Teori \& Praktik."
} 
be an efficient alternative solution to be implemented as a management system for quality control of Islamic education.

\section{References}

Andora, Dona, and Hade Afriansyah. "Pengendalian Manajemen Mutu Terpadu ( Total Quality Management)" (2019).

Asrohah, Hanun. "Manajemen Mutu Pendidikan." Government of Indonesia (GoI) and Islamic Development Bank (IDB). Surabaya: Universitas Islam Negeri Sunan Ampel Surabaya, 2015.

Bamawi, and M. Arifin. "Sistem Penjaminan Mutu Pendidikan Teori \& Praktik." Yogyakarta: Ar-Ru₹z Media (2017).

Hadi, Abdul. "Konsepsi Manajemen Mutu Dalam Pendidikan." Idaarah: Jurnal Manajemen Pendidikan 2, no. 2 (2018): 269. http://joumal.uin-alauddin.ac.id/index.php/idaarah/article/download/269-279/pdf.

Herawan, Endang. 'Pengendalian Mutu Pendidikan: Konsep Dan Aplikasi." Jurnal Administrasi Pendidikan 13, no. 1 (2011).

Hiryanto. "Pengendalian Mutu Program Pendidikan Non Formal Dan Informal." Yogyakarta: Bahan Diklat Fungsional Penilik, 2010. http://staffnew.uny.ac.id/upload/132049754/pengabdian/makalah-ppmpengendalian-mutu-program-pendidikan-nonformal.pdf.

Ishikawa, K, and D J Lu. Pengendalian Mutu Terpadu. PT. Remaja Rosdakarya, 1992. https://books.google.co.id/books?id=TXUXnwEACAAJ.

Jamali, Yusra. "Konsep Pengendalian Mutu Pendidikan." Tarbany: Jurnal Pendidikan Islam 1, no. 2 (2016): 304 318.

Jamaluddin. Manajemen MutuTeori Dan Aplikasi Pada Lembaga Pendidikan. Edited by Kasful Anwar Us. Jambi: Pustaka Jambi, 2017.

Mendikbud. Permendikbud No. 28 Tahun 2016 Tentang Sistem Penjaminan Mutu Pendidikan Dasar Dan Menengah. Kemdikbud, 2016.

Menristekdikti. Permenristekdikti No 62 Tabun 2016 Tentang Sistem Penjaminan Mutu Pendidikan Tinggi. Indonesia, 2016.

Mitra, Amitava. Fundamentals of Quality Control and Improvement. John Wiley \& Sons, 2016.

Prasojo, Lantip Diat. Maajemen Mutu Pendidikan. UNY Press. Yogyakarta: UNY Press, 2016.

Peraturan Pemerintah Republik Indonesia Nomor 19 Tabun 2005 Tentang Standar Nasional Pendidikan. Indonesia: 19 Tahun 2005, 2005.

S.A.P., Rangga Sa'adillah. 'Formulasi Kebijakan Pembelajaran Pendidikan Agama Islam; Refleksi Filosofis Kebijakan Permendikbud No . 22 Tahun 2016 Pada PAI.” El-Banat: Jurnal Pemikiran dan Pendidikan Islam 10, no. 22 (2020): 75-90.

- "Pembelajaran Pendidikan Agama Islam Berparadigma Kontekstual (Telaah Contextual Teaching and Learning Perspektif Teori Belajar)." TARBAWI 4, no. 1 SE-Articles (August 11, 2017). http://ejournal.kopertais4.or.id/susi/index.php/tarbawi/article/view/2916.

Sukmadinata, Nana Syaodih. 'Pengendalian Mutu Pendidikan Sekolah Menengah.” Bandung: Refika Aditama (2006).

Tanjung, Rahman, Cecep, Devi Sulaeman, Hanafiah, and Opan Arifudin. "Manajemen Pelayanan Prima Dalam Meningkatkan Kepuasan Mahasiswa Terhadap Layanan Pembelajaran (Studi Kasus Di STIT Rakeyan Santang Karawang)." Jumal Ilmiah MEA (Manajemen, Ekonomi, \& Akuntansi) 3, no. 1 (2019): 234-242.

Tobroni, Tobroni, Ishomuddin Ishomuddin, and Khozin Khozin. "Dampak Pendekatan Saintifik Terhadap Sikap Spiritual Siswa Dalam Pembelajaran PAI Di SMA Di Sidoarjo.” Jumal Pendidikan Agama Islam Joumal of Islamic Education Studies) 7, no. 2 (2019): 143-166.

Untari, Titin. "Implementasi Penjaminan Mutu Pendidikan Untuk Meningkatkan Mutu Pembelajaran.” In Seminar Nasional Kedua Pendidikan Berkemajuan Dan Menggembirakan, 389-400. Seminar Nasional Kedua Pendidikan Berkemajuan dan Menggembirakan, n.d. 